\title{
CULTURAL FACTORS ASSOCIATED WITH IRON DEFICIENCY ANAEMIA IN PREGNANCY: A CASE STUDY OF THE KALUTARA DISTRICT, SRI LANKA
}

\author{
Kalharie Pitigala \\ KAATSU International University, Sri Lanka
}

\begin{abstract}
Anaemia is a global public health problem that affects the social and economic development of a country. The objective of this study is to identify the cultural factors associated with iron deficiency anaemia in pregnancy. The study is largely qualitative and consisted of thirty anaemic mothers each; from urban, rural and estate sectors of the Kalutara district. The study revealed a connection between cultural factors and anaemia. Most anaemic mothers had refrained from contraceptives and meat due to religious principles. They believed that meat is considered as an evil food. Some had the belief that anaemia could be eliminated by traditional spiritual beliefs such as pooja and thovil. Such myths have refrained them from taking the iron supplement. The burden of iron deficiency could be eliminated by iron fortification programs, media awareness, improving the life style and education, support from the health sector and employing Tamil speaking PHMs.
\end{abstract}

Keywords: anemia, health, culture, pregnancy

\section{Introduction}

Approximately $30 \%$ of the world's population is anaemic, out of which $50 \%$ is due to iron deficiency anaemia (IDA). In the Sri Lankan context, the prevalence of anaemia in pregnancy is $29.3 \%$ (Chathurani et al, 2012) according to empirical statistics. It is a public health problem that affects populations in both rich and poor communities. Although the primary cause of anaemia in pregnancy is due to iron deficiency, it occurs due to other causes, such as chronic infection, nutritional deficiencies, and haemoglobinopathies.

Anaemia among pregnant women of Sri Lanka has been a long standing problem. Much quantitative research has been done with regard to this problem; however, their findings have not been able to combat its prevanace. Hence, there has been a need for an indepth study through a qualitative investigation into the causes of this problem. This study has qualitatively investigated the cultural factors that affect anaemia in pregnant women.

A study conducted in Galle, Sri Lanka reported prevalence of iron deficiency anaemia to be $40 \%$ among adolescents aged 12 to 16 years (Hettiarachchi et al, 2006). A study conducted by De Silva (2003) says "Iron deficiency is the major cause of anaemia in Sri Lanka (Ministry of Health, Sri Lanka, Policy Document 2000)" (p.234). Though there are latest advancements in the modern medicine, which highlights the importance of improved nutrition and the readily availability of cheap oral iron along with well-organized maternal and child care; anaemia with or without iron-deficiency persists to a large extent. It has become a worldwide problem. The research conducted so far has not been adequate to answer this issue. However, there is sufficient evidence to indicate that culture, beliefs and practices have a relationship to iron-deficiency anemia (Holliday, 2011). New findings also point to the need for more attention on maternal iron deficiency (Lozoff, 2007). As Shekar and Babu, (2009) has observed, maternal and child health $(\mathrm{MCH})$ is surrounded by a wide range of customs and beliefs all over the world.

Currently, the US government spends almost $\$ 6.5$ billion dollars on the women program of which anemia prevention is a major component. Iron deficiency anemia continues to afflict low-income, minority women of 
Child-bearing age living in urban areas of America as well as other countries (Holliday, 2011, World Bank). In contrast, developing countries such as in Nepal, the life expectancy of men eclipses that of women. Leading causes of death for women are identified as pre/post labor complications, hemorrhage, and infection. Cultural factors such as early marriage contribute to the problem, particularly in rural areas. (Armenakis and Kiefer, 2007).

This study is largely qualitative. It follows the case study method and has analysed ninety anaemic mothers. Purposive sampling has been used as the main sampling technique. The study units were taken from Panadura, Mathugama and Agalawatta $\mathrm{MOH}$ areas of the Kalutara district. Face to face in-depth interviews, questionnaires, key informants and focus group discussions have been utilized as the data collection techniques for this study. As this is mainly a qualitative research; open-ended, semi-structured methods have been frequently used for in-depth interviews. Content analysis has been used as the main data analysis technique.

Culture and/or ethnicity are factors that can contribute to our thoughts and attitudes. Both can have an impact on how people are raised, their core values, and their sense of family and tradition. The history of one's ethnicity, superstitious beliefs, and cultural beliefs are all things that can be passed down between generations and shape individual identities. This condition has led towards many health problems.

\section{Urban sector}

In the urban sector, Muslim community was identified with a pattern of extended families and it was evident as the pregnant mothers had not been given the opportunity of deciding their own meal when residing with an extended family. Also, the present study revealed that Muslim ladies have given priority to the males of the household when it comes to food. The males have been given the chance of eating first. One participant who was Muslim said that it is the tradition in their society to feed the males of the household first. As a result, there had been a couple of occasions where she has had to make do with the food that was left over and such food specifically lacked iron rich animal proteins or pulses. There were Sinhalese and Tamil anaemic mothers from the urban sector, who believed that red meat helped in increasing the $\mathrm{Hb}$ count. Apparently, their status of anaemia had gone down to mild level from moderate level after consuming red meat on a daily basis. However, most of the Sinhalese and Tamil mothers had the belief that consuming red meat is not good as it is heaty. They also believed that meat is considered as a food that creates a sense of evilness.

"We are not supposed to use family planning methods according to our religious principles, therefore, the gap between my first two children is just 11 months and I'm pregnant again with a gap of just 1 year between the second child and the one who is yet to be born", said Fathima who is a moderately anaemic mother.

\section{Rural sector}

Anaemic pregnant women belonging to the rural sector were superstitious. There were few Hindu anaemic mothers from the rural sector who pointed out cultural reasons for not consuming meat. They held a belief that not only red meat will help them recover from anaemia and their anaemic level has not been averted due to the fact that they did not consume meat due to cultural reasons. The Sinhalese and Tamils showcased a dislike towards meat consumption due to religious beliefs. One mother from the rural sector said that she is afraid to consume papaya because she has been told by her mother that the contamination of any milk from papaya could lead to an abortion. When her mother was questioned as to how she heard of it, she said that it is a common view that had been there since ages back and she had been told that by her mother. 


\section{Estate sector}

Anaemic pregnant women from the estate sector had lot of superstitious beliefs. They were under the impression that anaemia could be eliminated as a result of various traditional spiritual beliefs such as pooja and thovil. One of them had a belief that her body has been possessed by a devil and that is the reason for the lack of haemoglobin in her body. She was not aware of the term anaemia in any of the languages. Her belief was that the devil inside her body keeps drinking her blood and as a result the blood level goes down. "Lot of people in this surrounding are envious about me so it is obvious that I get their evil eye and evil mouth" (she expressed as "es waha kata waha"), says Lathakanthi (not the real name), an estate dweller who seemed to be quite carried away by superstitious beliefs. Most of the Hindus participated in the research were from the estate sector. They revealed that they have found it difficult to follow the diet and nutritional guidelines given by the obstetrician and the family health mid wife due to their religious beliefs. For example, they have refrained from consuming animal proteins.

According to the findings of the research; cultural influences show a significant impact on iron deficiency anaemia in pregnancy.

Inter-sectoral collaboration at a national level is an essential means of bringing more awareness to the public about iron deficiency anaemia. Also, it is important to note that counselling and other such services could provide more awareness and enhance the knowledge of the pregnant women. Educational events and dietary awareness programs related to effective methods of consuming iron rich food and other aspects of everyday living are factors that need to be closely considered. Routine distribution of informative flyers depicting anaemia, its causes and prevention methods would provide a good mode of spreading information amongst the masses. Further, the awareness sessions, clinic and medical camps conducted by the local health care providers are some of the ways that anaemia can be focused on.

Poverty eradication is also a major segment which the country, as a whole, needs to work on. Health services should be strengthened and it is mandatory to introduce an iron supplement with less complications. Providing health related material such as extra medication, food supplements or iron fortified food will also be beneficial.

Further, the media should be able to provide a wide coverage about health related issues to the public as a whole. Also, it is important to conduct these programs in all three languages.

State intervention is also vital in those aspects in order to improve the lifestyles and hygienic wellbeing of poverty ridden families. Issues such as lack of Tamil speaking PHM's in areas that are mainly populated by Tamil speaking families should be corrected immediately.

\section{References}

Adom, T., Steiner-Asiedu, M., Sakyi-Dawson, E., Alex, K., et al. (2010). Effect of fortification of maize with cowpea and iron on growth and anaemia status of children. African Journal of Food Science, 4(4), 136-142.

Armenakis, Alexis , Kiefer \& Christier. (2015, March 18). Social and Cultural Factors related to Health. Retrieved From

http://cugh.org/sites/default/files/content/resources/13_Social_And_Cultural_Factors_Related_To_Health_Part_ A_Recognizing_The_Impact\%20-\%20Copy.pdf

Ayoya, M.A., Spiekermann-Brouwer, G.M., Traore, A.K., Stoltzfus, R.J., \& Garza C. (2006). Determinants of Anaemia among Pregnant Women in Mali. Food Nutrition Bulletin, 27(3), 11.

Baker, D. (2006). The Meaning and the Measure of Health Literacy. Journal of General Internal Medicine, 21(8), 878-883. 
Chathurani, U., Dharshika, I., Galgamuwa, D., Wickramasinghe, N., Agampodi, T. \& Agampodi, S. (2012). Anaemia in Pregnancy in the district of Anuradhapura, Sri Lanka--need for updating Prevalence data and Screening Strategies. Ceylon Medical Journal, 57(3), 11-106.

DeMaeyer, E.M. (1989). Preventing and controlling iron deficiency anaemia through Primary Health Care. A guide for health administrators and program managers. Geneva: WHO

DeMaeyer, E. \& Adiels-Tegman, M. (1985). The prevalence of anaemia in the world. La prevalence de lanemie dans le monde. World health statistics quarterly. Rapport trimestriel de statistiques sanitaires mondiales, 38(3), 302-16.

Dreyfuss, M., Stoltzfus, R., Shrestha, J., Pradham, E., Leclerq, S., \& Khatry, S. (2000). Hookworm, malaria and vitamin A deficiency contribute to anemia and iron deficiency among pregnant women in the plains of Nepal. Journal of Food Nutrition, 130, 2527-2536.

De Silva, A., Atukorala, S., Weerasinghe, I. \& Ahluwalia, N. (2003). Iron supplementation improves iron status and reduces morbidity in children with or without upper respiratory tract infections: a randomized controlled study in Colombo, Sri Lanka. The American Journal of Clinical Nutrition, 77(1), 234-241.

Goel, S., \& Gupta, B.P. (2007). Low Anaemia Prevalence among Adolescents of an Urban Hilly Community. Indian Journal of Community Medicine, 32, 76-68.

Goonewardene, M., Seekkuge, J., \& Liyanage, C. (1995). Iron Stores and its correlation to Haemoglobin levels in Pregnant Women attending an Antenatal Clinic. Ceylon Medical Journal, 40, 67-69.

Hettiarachchi, M., Liyanage, C., Wickremasinghe, R. et al. (2006). Prevalence and Severity of Micronutrient deficiency: A Crosssectional study among Adolescents in Sri Lanka. Asia Pacific Journal of Clinical Nutrition; $15,56-63$

Holliday, R. (2011). Anemia Prevention: Development of a Theory-Driven Nutrition Education Measurement Instrument. Doctoral Dissertation, University of Connecticut.

Jombo, G., Mbaawuaga, E., Ayegba, A. \& Araoye, M. (2011). Anaemia, malaria burden and its control methods among pregnant women in a semi-urban community of northern Nigeria. Journal of Public Health and Epidemiology, 3(7), 317--323.

Karaoglu, L., Pehlivan, E., Egri, M., Deprem, C., Gunes, G., Genc, M. et al. (2010). The prevalence of nutritional anemia in pregnancy in an east Anatolian province, Turkey. BMC Public Health, 10(1), 329.

Lozoff , B. (2007). Iron deficiency and child development. Retrieved March 10, 2015, from http://www.ncbi.nlm.nih.gov/pubmed/18297894

Qureshi, M., Khan, S., Farzana, K., Murtaza, G., Azhar, S., Noreen, S. et al. (2012). Prevalence of iron deficiency in adult population: A case study from Khyber Pakhtunkhwa (KPK), Pakistan. International Journal of Physical Sciences, 7(11), 1874-1877.

Rajapaksa, L., Arambepola, C., Gunawardene N. (2011). Nutritional status in Sri Lanka, determinants and interventions: a desk review $2006-2011$.

Shekar, Chandra, B.R., \& Babu, R.P. (2009). Cultural factors in health and oral health, Indian Journal of Dental Advancement, 01(8). Retrieved February 06, 2015, from http://www.nacd.in/ijda/ -cultural-factors-in-healthand-oral-health

WHO. (2014). Micronutrient deficiencies. Retrieved January 25, 2014, from http://www.who.int/nutrition/topics/ida/en/

World Bank. (2011). Nutrition at a Glance, Sri Lanka. Retrieved March 11, 2015, from http://siteresources.worldbank.org/NUTRITION/Resources/281846-1271963823772/SriLanka.pdf

World Health Organization. (1995). Physical status: the use and interpretation of anthropometry. Report of a WHO Expert Committee. WHO Technical Report Series No. 854. Geneva. 